\title{
IMÁGENES PERFORMATIVAS Y RACIALIZACIÓN EN La Obra De Pedro Figari. Apuntes Sobre LA Normalización DE Los Cuerpos Negros EN El Río DE LA Plata
}

\author{
Manuela Rodríguez. \\ Universidad Nacional de Rosario \\ Consejo Nacional de Investigaciones Científicas y técnicas \\ manuela.guez@gmail.com
}

Resumen: Este trabajo profundiza en la representación de la cultura afrorioplatense que el pintor Pedro Figari (1861 - 1938) realizó a comienzos del siglo XX, en el marco de una producción de vanguardia que buscaba dar sustento a un ethos propiamente "americano" y nacional. A partir de una pregunta sobre el lugar que el arte tuvo en la construcción de una "negridad" local, analizo su obra pictórica, junto a ciertos discursos vigentes en la época (del propio artista y de algunos intelectuales contemporáneos), como un dispositivo biopolítico de racialización, que hizo foco en el cuerpo negro, sus capacidades y su cultura. Ahondaré en el papel que jugó su producción en la construcción de un imaginario racial altamente performativo, pues produjo "imágenes corporizadas" que colaboraron en la creación de sentidos, percepciones, impresiones, estéticas y actuaciones performáticas vinculadas a la identidad afro-rioplatense que continúan vigentes hasta nuestros días. Una de las hipótesis que sostengo es que existe algo así como un "sello regional" de lo negro en esta zona, fuertemente influido por la obra de este pintor, que indica cómo es posible mostrar y visibilizar lo negro de forma legítima para el contexto nacional, tanto argentino como uruguayo. Y propongo que este "sello regional" es producto, en parte, de este proceso histórico de racialización de imaginarios, sujetos y prácticas que se produjo a través del cruce y la retroalimentación ocurrida entre artistas e intelectuales en la tarea de dar forma y contenido a las recientes naciones.

Palabras clave: Racialización, Performatividad, Imaginarios, Río de la Plata, Pedro Figari.

Abstract: This work delves into the painter Pedro Figari's representation of Afro-Rioplantense culture, at the beginning of the 20th century, in a context of an avant-garde production that sought to support an "American" and national ethos. Based on a question about the place of art in the construction of a local "blackness", I analyze his pictorial work, along with certain prevailing discourses of the time (of the artist himself and some contemporary intellectuals), as a biopolitical device of racialization, which focused on the black body, its capabilities and its culture. Thus, I intend to gain a better insight into the role that his production played in the construction of a highly performative 
racial imaginary. It is my believe that the "embodied imagery" his work produced, helped to create senses, perceptions, impressions, aesthetics and performances linked to the AfroRioplatense identity that remain valid until today. One of my hypotheses is that there is a "regional stamp" of blackness in this area, strongly influenced by the work of this painter, which makes it possible to show and make legitimately visible "blackness" within national context, both Argentine and Uruguayan. Furthermore, I propose that this "regional stamp" is the product, in part, of this historical process of racialization of imaginary, subjects and practices that occurred through the crossing and feedback between artists and intellectuals in their task of giving form and content to recent nations.

Keywords: Racialization,

Performativity, Imaginary, Rio de la

Plata, Pedro Figari.

\section{Introducción}

...más que nada me ocupé de reordenar mis recuerdos acerca de nuestra tradición, virgen como se presentaba, en un campo por entero inculto, puede decirse [...] Entonces me dije: 'yo trataré de fijar mis recuerdos según pueda, y estos servirán a los artistas nacionales para reconstruir nuestra tradición' (Pedro Figari, 1938, en Sanguinetti 2002, p. 202).

Querido amigo Figari, pintor de la tierra mía usted nunca imaginó, que un candombe le daría

De tanto mirar sus cuadros, aquí y en tierras vecinas me di cuenta que pintó, música como la mía (...) Don Figari, compañero de la vida hay que ver con que dulzura, pintó usted la raza mía Rompen las lonjas, rompen, parche y madera morena dale a la lonja moreno, 
que resuenen los candombes, por Figari una vez más (...) La música y la pintura, andan por la misma vía Usted pinta la emoción, yo versos con armonía Querido amigo Figari, pintor de la tierra mía (Letra y música: Rubén Rada)

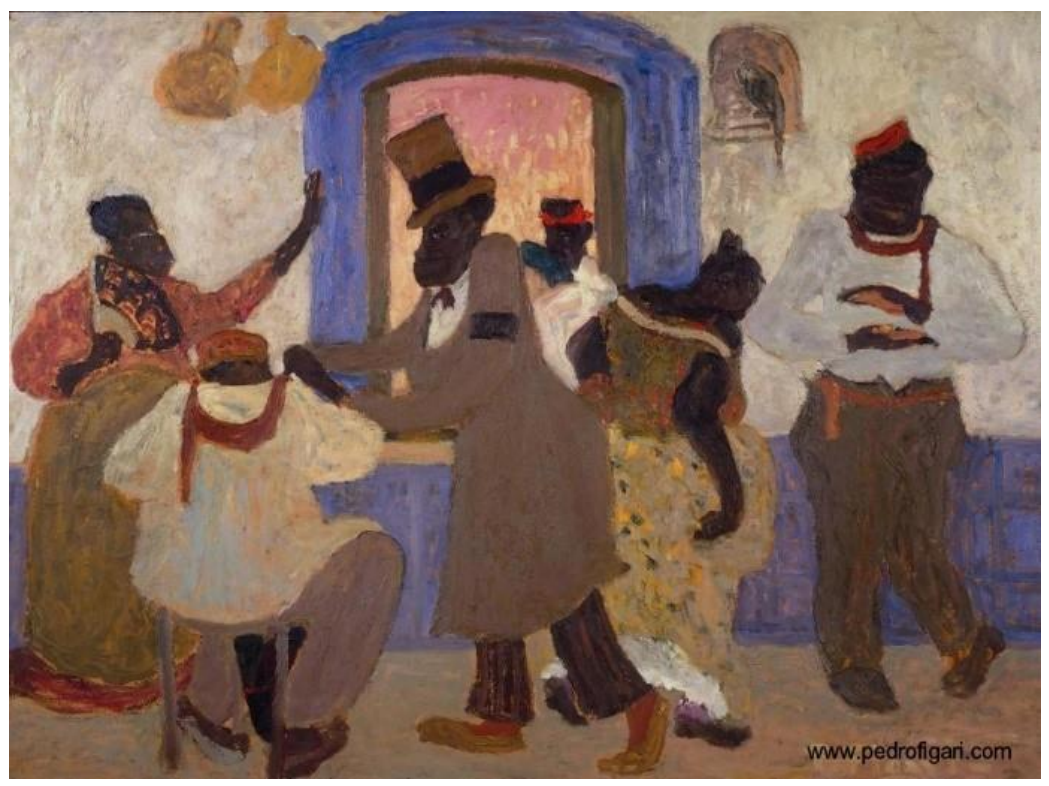

Fig 1: Pedro Figari, Candombe s/f 


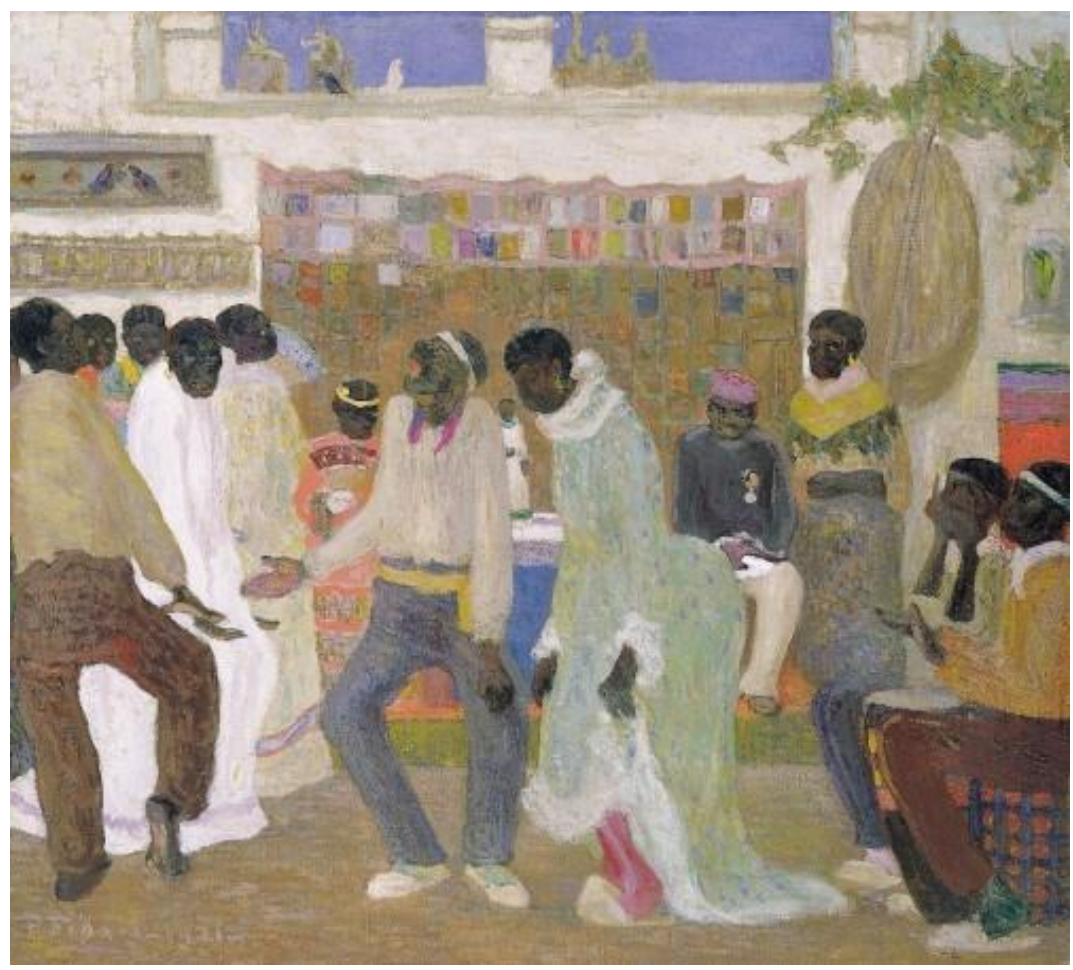

Fig 2: Pedro Figari, Candombe, 1921

El presente trabajo nace de una inquietud por la corporalidad. En primer lugar, porque los cuadros del pintor Pedro Figari sobre el candombe afrouruguayo fueron una impresión en mi retina desde el primer día que me acerqué a esta práctica cultural para bailarla y luego para investigarla. Cualquiera que se acerque en profundidad al candombe sabe que allí se baila una danza "figariana": su trazo colorido,

1 Baste hacer un pantallazo general en Internet con la palabra candombe para que aparezcan, irremediablemente, las representaciones realizadas por Figari para ilustrar esta práctica. Su vigencia es tal, como forma ineludible para enseñar sobre esta historia afrorioplatense, que puede apreciarse su uso pedagógico actual en uno de los folletos que elaboró, en 2014, el área de Educación y acción cultural del Museo de Arte 
impresionista, ha calado en la representación corporal y en la producción de un imaginario sobre esta práctica cultural. En segundo lugar, porque mi acercamiento actual a la obra pictórica de este autor surge de una pregunta anterior sobre la biopolítica en las dos vertientes planteadas por Foucault (1977, 2000, 2006): el del disciplinamiento de los cuerpos y el de la gubernamentalidad de las poblaciones. En su noción de racismo de estado, tal como lo desarrolla en Defender la sociedad (2000), Foucault vincula el surgimiento de la biopolítica con el pasaje del gobierno soberano al gobierno de la población, a través de tecnologías que apuntan a hacer vivir y dejar morir. Esta mutación del poder ocurrida a partir del siglo XVIII toma a su cargo la vida de los hombres como cuerpos vivientes, y pasa del ejercicio del poder formulado en los términos del derecho jurídico como poder centrado en la extracción y la muerte, a procedimientos técnicos que ya no se apoyaban en la ley sino en la normalización. Así, la población que es tomada como objeto de la biopolítica supone un exterior de seres humanos dispensables que se pueden dejar morir o, incluso, hacer morir siempre y cuando se haga en nombre del hacer vivir de la propia población. Esta es la lógica del racismo moderno que, en palabras de Restrepo (2011, p. 136) hace surgir a la racialización en el terreno de la gubernamentalidad: del gobierno de los otros y de sí mismos.

Latinoamericano de Buenos Aires (MALBA) para enseñar su legado y su influencia sobre la cultura afro local. Consultarlo en: http://www.malba.org.ar/wpcontent/uploads/2014/04/Figari.pdf. También se puede observar una propuesta similar, elaborada por el Museo Nacional de Buenos Aires, en: http://www.bnm.me.gov.ar/erecursos/recursos_didacticos/portafolios/asamblea_xiii/ pintura.htm 
Si este racismo de estado, articulado al dispositivo de sexualidad que Foucault desarrolla en Historia de la sexualidad (1977), está planteado como un desarrollo de la sociedad europea occidental que se acentúa y se consolida en el siglo XVIII, me parece interesante observar, al menos como hipótesis inicial, que ese fue el momento de mayor ingreso de esclavos al continente americano. Por lo cual, en América, la colonización, devenida luego en colonialidad (Quijano 2000, Castro-Gómez 2014) se erigió sobre la normalización de aquellos cuerpos "otros", que fueron, en la gramática de la guerra trabajada por Foucault, "los vencidos". ¿Qué lugar ocuparon los que fueron el reverso negativo de lo "normal"? Pienso fundamentalmente en los sectores marginados de ese sistema (o utilizados como margen) -en América Latina: en los esclavos e indígenas primero, y luego en los inmigrantes externos e internos- y con ellos todas sus formaciones culturales en donde lo corporal jugaba un rol determinante.

En este sentido, fueron mis preocupaciones iniciales sobre la corporalidad, las prácticas rituales y festivas de la población afrodescendiente y la materialización de identidades racializadas en el contexto del Río de la Plata (Rodriguez, 2007, 2016) las que me llevaron a indagar en los imaginarios raciales como formas de gobierno de los cuerpos de la nación. Así, este trabajo, resultado de un proyecto de investigación para una adscripción que realicé en la materia: "Problemática del arte latinoamericano del siglo $\mathrm{XX}^{\prime 2}$, tuvo desde un comienzo,

\footnotetext{
2 Esta materia es parte del programa curricular de la carrera de Bellas Artes, en la Facultad de Humanidades y Artes de la Universidad Nacional de Rosario, y se encuentra a cargo de la Dra. Laura Catelli. Mi mayor agradecimiento a su generosidad por haberme
} 
como objetivo general, articular el problema de "las bellas artes" con el de la producción de imaginarios y prácticas racializadas. Dicho proyecto se proponía rastrear, en el arte latinoamericano del siglo XX, aquellas producciones que se habían detenido especialmente en la representación de un legado, una cultura y una corporalidad "negra", con el fin de comprender el rol que tuvieron los artistas en la construcción de una "negridad" particularmente latinoamericana.

Se fue conformando, así, un interrogante por lo racial, por la raza y por la racialización como proceso, en los términos no exclusivos de una práctica artística, sino bajo el lente del análisis de las prácticas corporales, inter-subjetivas y fuertemente experienciales. Esto quiere decir, apuntar hacia la articulación de lo racial con la praxis, analizando cómo las prácticas producen y son producidas, no sólo por discursos, sino, fundamentalmente, por sensibilidades y afectaciones. En este sentido, la producción de la diferencia racial en el marco de una discusión sobre la biopolítica, es también una pregunta por el asco, por el rechazo y por el deseo. El biopoder actúa no sólo en los términos de la restricción y el control, sino, también, en los términos de la producción de intensidades y placeres que se articulan, como bien lo dijo Foucault, con la producción de subjetividades. Y aquí entraría Pedro Figari con sus cuadros sobre el candombe. ¿Qué producen, y qué produjeron, en términos de sensibilidad, sus cuadros sobre las prácticas afrouruguayas? Y cómo es posible que sólo él se haya detenido en esta representación; o, dicho de otra manera: qué

invitado a ser parte de un grupo de trabajo con el cual pensar y elaborar interrogantes sobre esta problemática compleja que articula racialización e imaginarios. 
tiene de especial su representación de los negros uruguayos que agotó todo aquello que podía ser expresado en el circuito del arte, cobrando tal visibilidad y aprecio entre los circuitos de vanguardia $y$, más tarde, entre la misma comunidad afrodescendiente. Por qué y con qué motivos logró decir "todo" sobre los negros, tanto como para que nadie se haya detenido en producir una representación distinta, que le conteste $\mathrm{o}$, al menos, que le dialogue. La respuesta está, considero, en un análisis de su obra en el marco de un contexto histórico político muy particular: el de la conformación de un imaginario nacional y regional que de fundamento y cohesión a los nacientes estados. Estados que tomaron a su cargo la gubernamentalidad de poblaciones profundamente heterogéneas, que debían ser disciplinadas y normalizadas bajo parámetros raciales y sexo-genéricos bien específicos.

En este marco de discusiones, me propuse comprender cómo sus cuadros colaboraron y colaboran aún hoy en la creación de sentidos, percepciones, impresiones, estéticas y producciones performáticas vinculadas a la identidad afrorioplatense; y cómo, su propuesta, se articula con una forma legítima de mostrar y visibilizar lo "negro" en los contextos nacionales, tanto argentino como uruguayo. En otras palabras, que imágenes construyó sobre la cultura de los negros de esta región, y qué incidencia tuvo su obra en la producción de un imaginario racial regional con fuertes efectos performativos. Parto de considerar que el uruguayo Pedro Figari es una clave fundamental del imaginario negro de la zona del Río de la Plata, e incluso más allá, hacia el Litoral argentino, pues su 
obra tuvo y tiene grandes resonancias en las representaciones y prácticas referidas a los afrodescendientes de la región. Si bien su producción pictórica fue tardía en su vida, en poco tiempo instaló un mundo afrouruguayo que traspasó las fronteras de su país hacia el exterior. Pedro Figari Solari (1861 - 1938), hijo de inmigrantes italianos residentes en Montevideo, fue abogado, político, escritor, periodista y, posteriormente, pintor. Es decir, su pintura podría considerarse como la culminación estética de una vida intensa en la cual la reflexión y la gestión en materia de políticas públicas cobró un lugar fundamental. Su interés plástico devino, entonces, como resultado de un profundo compromiso con su tiempo, sus contemporáneos y su decisión de intervenir en la vida nacional. Lo cual da cuenta de que aquello plasmado estéticamente fue una búsqueda racional y consciente, y podría decirse, hasta pedagógica; como queda claro en el epígrafe que citamos: "yo trataré de fijar mis recuerdos según pueda, y estos servirán a los artistas nacionales para reconstruir nuestra tradición". Esto permite, aún más, situar su obra como un marcador generacional que intentaba influir en la percepción y valorización de las generaciones futuras en materia de historia nacional, memoria e identidad. $\mathrm{Al}$ pertenecer a una generación anterior a la llamada "vanguardia del '20", su influencia se hizo sentir más como un legado, o como un padrinazgo desde el cual fundamentar la búsqueda de una identidad propia, netamente americana.

De esta manera, el presente artículo abordará, en un comienzo, algunas propuestas sobre la eficacia performativa que puedan tener sus obras en este contexto de profunda transformación social, indicando algunas cuestiones vinculadas 
a la representación, la imagen y la corporalidad como categorías analíticas que se interceptan. En este sentido, propondré la necesidad de considerar a la obra pictórica como productora de "imágenes performativas" que intervienen y producen lo social de manera profundamente afectiva y sensible, mediante el establecimiento de percepciones, sentidos e imaginarios racializados. En el siguiente apartado me detendré en algunos aspectos claves de la vida y obra de Figari que nos permitan comprender su producción pictórica de manera contextual, como producto, pero, también, como productor de su propio tiempo. Finalmente, esbozaré algunas conjeturas sobre la influencia de su pintura en la creación de un imaginario muy particular sobre los negros y su cultura en esta zona, con fuertes efectos performativos, pues incide allí donde la imagen se hace carne, pues busca, muy insistentemente, afectar al espectador desde la impresión, dejando una huella emotiva sobre los negros que continúa, de cierta manera, vigente aún hoy.

\section{Imágenes performativas: obra pictórica y racialización}

"Mi pintura no es 'una manera de hacer pintura' sino un modo de ver, de pensar, de sentir y sugerir" (Pedro Figari en Laluz, 2012). 
Antes de ingresar a la obra pictórica de Pedro Figari, me gustaría detenerme en dos términos que son claves para este trabajo: representar y cultura. Lo primero que deberíamos plantear es que Figari, en su faceta artística, no elaboró una representación de la cultura de los afrouruguayos de su tiempo, sino que decidió representar una cultura "imaginada" por él, un recuerdo de su pasado. Este imaginar, plasmado en imagen pictórica, si lo pensamos en términos de la teoría performativa (Butler 2004, 2008), "produce lo que nombra". Varios autores se detuvieron en la eficacia performativa del arte, en especial de las artes del movimiento o del arte escénico (Citro 1997, 2001, 2006; Schechner 2000, Taylor 2003), indagando en la manera en que estas producciones estéticas intervienen en la creación de mundo, de lazos sociales y en la conformación de valores, sentidos y, especialmente, sensibilidades. Este abordaje se cruza con las discusiones sobre la problemática de la corporalidad como procesos de materialización de cuerpos e identidades que están profundamente atravesadas por diferenciaciones de sexo/género, raza, clase y demás adscripciones. Desde esta perspectiva, este proceso de materialización se produce a partir de prácticas performativas que al "decir", nombrar, representar o hacer, producen su referente; es decir, lo citan y al citarlo lo re-crean (Rodriguez 2018). Propongo, así, que esto es lo que hace Figari cuando pinta "sus" negros: re-crea negros legítimos, primero para los vanguardistas porteños, luego para los parisinos, y bastante posteriormente para sus contemporáneos montevideanos.

¿Por qué y cómo realiza esto? Para contestar esta pregunta, retomo la categoría de imágenes (o metáforas) corporizadas (embodied 
imagery) de Thomas Csordas (antropólogo y creador de lo que denominó como fenomenología cultural). Para este autor, es preciso concebir una noción de imagen que no esté anclada a la tríada mental-visual-representacional; es decir, es preciso entenderla como un fenómeno que puede ocurrir en todas las otras modalidades de los sentidos. Esto es así porque, según su planteo, la imaginación es un proceso concreto, surgido de una profunda y vívida unión de propiedades sensoriales. Una imagen no es simplemente observable, en verdad podría decirse que una imagen es vivida y experimentada a partir de un entramado en el cual están involucrados todos los sentidos. Csordas propone así que la constitución de la síntesis intersensorial se da a través de la imaginación, sugiriendo con ello que el análisis de las imágenes corporizadas en una cultura determinada revela la constitución imaginaria de la intersubjetividad y la transitividad (entre los sujetos) dada a través de la mimesis. Esta es una organización sensorial favorecida por la socialización en común, y en la cual la mimesis anclada en el imaginario juega un rol importante (Csordas, 1999, p. 154). En este sentido, las imágenes producen inter-subjetividad, pero no porque representen algo que está fuera de ellas, sino porque logran hacerlo presente al conjugar sentidos y sensibilidades con materialidades subjetivas en contextos sociales específicos. Estos contextos están atravesados por innumerables relaciones de poder, entre las cuales se encuentra la dinámica racial como un proceso que se articula también y se concreta partir de estas imágenes.

Esta noción de imagen que propongo está vinculada a la fenomenología y al concepto de esquema corporal de Merleau- 
Ponty (1993), el cual, oponiéndose a la división cuerpo/mente, postula la existencia de un conocimiento práctico y sensible del mundo. En la teoría de este autor, el cuerpo es el acceso al mundo del sujeto, un mundo inter-subjetivo que se despliega pre-objetivamente, es decir, antes de pasar por la conciencia, y que es primordialmente sensible. Así, el esquema corporal es definido como una modalidad dinámica del ser-en-el-mundo que se caracteriza por "existir hacia las cosas" y "recogerse en sí mismo" para alcanzar su objetivo (1993, p. 117). Este esquema corporal, producto del vínculo instituyente del sujeto con los otros y con el entorno, adquiere una dimensión política más compleja cuando se lo considera como producto de relaciones que están afectadas por las diferenciaciones que en una sociedad delimitan lo propio y lo ajeno, lo normal y lo abyecto, lo deseable y lo indeseable. Para el caso que estamos abordando, tal vez sea más acertado hablar de esquema epidérmico racial, en los términos de Frantz Fanon (1973), como una corporalidad negra henchida de imágenes que son profundamente performativas al establecer lo que esa corporalidad puede y no puede ser/hacer. En particular, cargada de estereotipos, como dice Bhabha (2002), intrínsecamente ambivalentes; un imaginario racial que tiene espesor, produce cosquilleo, eriza la piel o puede dar náuseas (De Oto y Bulo, 2015).

En los términos de Catelli (2017), lo "imaginario racial" debe ser entendido como ese proceso dinámico de relaciones en el cual se produce la racialización (a través de discursos, prácticas, espacios y sujetos) en un contexto determinado. Atendiendo a los aspectos simbólicos e imaginarios de los 
dispositivos que sostienen y ponen en movimiento las formaciones raciales locales, la autora propone abandonar una idea sustancialista de la raza, hacia una comprensión dinámica. Esto permitiría hacer un registro analítico de los mecanismos, a veces subrepticios, con que opera la racialización, en especial a nivel institucional, pues allí se juegan procesos relacionales vinculados a lo imaginario (2017, p. 98). Desde esta perspectiva, pretendo comprender cómo en el ámbito de las artes instituídas (pero no sólo allí, sino en el entramado que éste tiene con otros ámbitos del saber experto) se produce un imaginario racial que funciona como saber y como experiencia legitimada en relación con los negros. Así, intentaré focalizar, no sólo en el nivel de lo simbólico, sino en el nivel de lo sensible, de la afectación que sus cuadros provocan y por el cual están elaborados bajo una técnica formal específica, razón por la cual la temática "negra" llega a cobrar tal visibilidad y aceptación social. Es la articulación entre forma y contenido plasmado en esas imágenes lo que produce esa eficacia performativa que hace surgir un saber y un sentir negro particular en esta zona. Antes de avanzar sobre esta idea, quisiera adentrarme en el contexto histórico social de producción de la obra de Pedro Figari.

\section{Entre tradición y modernidad: la obra de Pedro Figari}

Retomando los estudios de Artundo (2000a y b), Pandre (2014) y Schwartz (2006), presentaré una breve contextualización de la obra de Pedro Figari, situando su 
particular relación con la vanguardia argentina y uruguaya de los años '20.

Pedro Figari se recibió, a los 24 años, de doctor en Jurisprudencia por la Universidad de la República, y publicó una Tesis de grado sobre la Ley Agraria en la cual "define las principales carencias estructurales de un país que pugna por ser moderno pero que sigue caminos dispares para lograrlo, en una permanente contradicción" (Anastasía y Rela en Pandre, 2014, p. 11). Su padrino de tesis y de grado fue el Dr. Carlos de Castro, distinguido hombre público, ministro de Estado, diplomático, senador de la República y figura principal de la masonería en el Uruguay. En junio de ese año Figari ocupó el cargo de Adjunto a la Fiscalía de Hacienda y al año siguiente se casó con Da. María de Castro Caravia, hija de D. Carlos de Castro. El matrimonio viajó a Europa, visitando Francia, Inglaterra, Alemania, Austria, Bélgica, Holanda y Dinamarca y, al regresar a Montevideo, residieron en una de las propiedades de la familia Castro. Algunos hitos de estos primeros años de su juventud fueron: en 1889 fue designado Defensor de Pobres en lo Civil y en lo Criminal; en 1893 fue co-directorfundador de El Deber, diario de la fracción liberal del Partido Colorado; en 1897 fue electo diputado del Partido Colorado por el departamento de Rocha y luego por el departamento de Minas; en 1903 presidente del Ateneo de Montevideo; en 1905 publicó, en el diario El Siglo de Montevideo, 22 artículos a favor de la abolición de la pena de muerte; en 1912 el Presidente de la República, en acuerdo con el Ministro del Interior, lo designó Miembro del Consejo de Asistencia Pública Nacional, ese mismo año publicó Arte, estética, ideal y en 1913 viajó a Paris 
en donde visitó al pintor uruguayo Pedro Blanes Viale y se relacionó con los grupos intelectuales interesados en la producción cultural latinoamericana.

El objetivo de esta breve cronología es dar una idea del circuito social en el cual Pedro Figari se movía, constituida por una elite de funcionarios públicos, intelectuales, artistas y políticos de alto renombre. En este sentido, y tal como lo dice Segato, fue esta generación del '80 la que construyó un discurso "literario-administrativo", y agregaría estético, que "legisló para la nación moderna mientras elaboraba la mitología que le dio identidad" (1991, p. 255). Es esta retroalimentación entre intelectuales, políticos y artistas la que quisiera señalar para enmarcar la obra de Figari.

En esta búsqueda por dar sustento a lo propiamente nacional es que deben entenderse los lineamientos propuestos por Figari cuando lo nombran, en 1915 y a los 43 años de edad, director de la Escuela Nacional de Artes y Oficios de Uruguay. Uno de los objetivos de la reforma puesta en marcha fue, en sus propias palabras:

... no hacer sino cosas originales, y todo lo americanas que fuese posible (...) Eso propendía por un lado a despertar el espíritu de observación amplia, libre de prejuicios, y por el otro a descubrir los elementos autóctonos, su fisonomía que debió ser fruto de la tradición en el ambiente precolombino, y por lo propio estimable y lógica- con lo cual se iba modelando un espíritu autóctono americano, no simiesco y comodón (en Pandre, 2014, p. 60). 
Según Linari, Figari buscaba el desarrollo de una nueva educación en la cual materializar un arte regional, que "contó con los motivos de la flora y fauna nacionales, así como también con los de la utilería prehispánica indoamericana" (en Artundo, 2000b, p. 4). Como dice Pandre, en su insistencia por llevar el arte a la industria, él se proponía juntar los preceptos materialistas burgueses del siglo XX con los ideales de sublimación a través del arte proveniente del siglo XIX. Al ser un hombre educado con valores humanistas, se enfrentó en su madurez con los objetivos prácticos de la nueva mentalidad burguesa propia de los comienzos del 1900. En él se producían, entonces, una conjunción de valores ligados a la necesidad de modernización sin abandonar una búsqueda estética ligada a la tradición. Su identificación con lo propiamente americano se oponía al consumo de la burguesía del Uruguay de esa época que acostumbraba importar productos de Europa en aras de demostrar prestigio social a través del arte (Pandre 2014, p. 15).

Cuando en 1921 es nombrado Asesor Letrado de la Legación de la República Oriental del Uruguay en Argentina, se instaló en Buenos Aires, con 60 años, decidido a incursionar en su veta artística. Allí se conectó con Ricardo Güiraldes, hijo de Don Manuel Güiraldes, hacendado y funcionario público argentino que llegó a ser Intendente de Buenos Aires entre 1908 y 1910, realizándose durante su gestión los festejos del Centenario de la Revolución de Mayo. Ricardo compró parte de sus obras y lo ayudó a insertarse en el ambiente artístico. Luego viajaría a París para participar de exposiciones y captar 
los lineamientos del Modernismo. El interés de Europa por el universo americano permitió la entrada de su obra en los circuitos de las elites culturales francesas. De esta manera, el viejo continente comenzó a incorporar tópicos, imágenes y conocimientos sobre la pampa, los gauchos y los negros de esta región.

La "Pampa" de Figari compartió, con la de Jules Supervielle, la posibilidad de introducir ciertas claves americanas en el "sistema digestivo de la cultura europea". Tal posibilidad estaba, para el caso de la pintura de Figari, favorecida por la clara continuidad que esta obra presentaba con respecto a la tradición del realismo humorista y crítico decimonónico (Goya, Daumier), y con la más reciente instancia del postimpresionismo, representada por Bonnard y los intimistas franceses (Linari en Pandre 2014, p. 6).

\section{Sugestiones y recuerdos primitivistas}

...mi arte...justamente es esto: yo no trato de definir, ni de dar una noción precisa de la realidad objetiva, ritual, sino de ofrecer por sugestión briznas de realismo más o menos poetizando según mi manera personal de reaccionar, de ese realismo que he podido anotar en mi observación y en mis recuerdos (Figari en Pandre 2014, pp. 16-17).

El predominio de Figari por retratar lo propiamente regional se alimenta del imaginario literario de la época, como la 
literatura gauchesca de Antonio Lussich y Ricardo Güiraldes. Su particularidad es que fue uno de los pocos artistas de la zona rioplatense que propuso considerar la vida y la cultura de los negros como parte de un acervo cultural común, regional. Así, los pintó en diferentes ámbitos: realizando sus tareas domésticas, en bautismos, casamientos, funerales y principalmente bailando el candombe. En sus cuadros distingue, especialmente, el movimiento corporal en forma de danzas, toques de tambor, contacto corporal, aglomeración y desarticulación de los cuerpos. Lo interesante de notar aquí es que la justificación de sus pinturas está en el "recuerdo", un recuerdo de la niñez cargado de sugestión e impresión. Veamos cómo lo dice Figari en una conferencia en París:

Mi pintura es fruto de observación directa del ambiente, y para facilitar mi obra hube de remontarme a mis recuerdos, puesto que es allí, donde se encuentran los tipos genuinos de América, del país; desaparecidos y en un enjambre abigarrado de costumbres y vestimentas: todo ello en tren de constante reforma de transformación (en Pandre 2014, pp. 16-17).

Es decir, los tipos genuinos de América sólo pueden estar en el recuerdo, pues en la contemporaneidad están irreversiblemente en transformación. Pensemos en un entorno en el cual la llegada masiva de europeos pobres cambió drásticamente la fisonomía sociocultural, y en donde la memoria es garante de autenticidad, en el momento en que es testigo de un pasado al cual los recién llegados están 
inhabilitados. Recordar, tener impresiones del pasado, es una forma de legitimar lo propio ante el avasallamiento extranjero. Pero, además, específicamente en relación con los afrodescendientes, esa memoria carga con sentidos y apreciaciones muy particulares. La cita que sigue es ilustrativa del entorno en el cual Figari se mueve, y de cómo se nutre también este "recuerdo" de sentidos sobre los negros y sobre África que circulaban en su ámbito social. Dice:

Los negros: impresiones que recogí cuando niño, al ver los candombes rituales, las que me parecieron deslumbrantes, y que se presentaban a mi recuerdo en torbellino, como en un kaleidoscopio encantador, lleno de sugestiones pintorescas. Acaso eso fue lo que más tarde me hizo interesar en los relatos africanos del doctor Livinsgton, de Stanley, de Speke, y otros que leí con avidez (...) Yo veía humanos nimios en aquellos salvajes adaptados a la vida primaria, colonial, y los relatos que leí me confirmaron en cuanto a que la palabra "salvaje" tiene en su entraña más de pueril que de terrible, según se la encara generalmente. La forma en que se procedía al tráfico de negros me hizo ver que los civilizados muestran a veces más crueldad de la que se expende en la selva africana, y al ver la fidelidad, la solicitud y la ternura de los esclavos para con sus amos, comprendí que se vivía en completo engaño al considerar las cualidades de dicha raza. Lo que ocurrió con Livingstone (Figari en Pandre 2014, p. 32). 
$\mathrm{Al}$ respecto vale hacer algunas apreciaciones. Por un lado, que es muy probable que Figari haya podido ver las prácticas rituales y de sanación de los africanos esclavos y libertos en su entorno, pues al menos hay registro histórico hasta 1893, cuando José Ingenieros describe una ceremonia religiosa afroargentina ${ }^{3}$, lo que hace suponer que su presencia estaba también en Uruguay. Asimismo, en Montevideo, el proceso de constitución y transformación de las Cofradías a las Naciones y Sociedades de ayuda mutua de afrodescendientes, con sus fiestas particulares, y su participación en los carnavales oficiales no dejó de ser una constante hasta nuestros días, aún con sus profundas mutaciones (Rodriguez 2007). Todo lo cual hace suponer que ese contacto con "lo negro" estuvo cargado de esa fascinación y rechazo (Reid Andrews 2006, p. 92) tan característica del vínculo racial producido en los países americanos.

En otro comentario, deja entrever este tipo de apreciaciones:

\footnotetext{
${ }^{3}$ Ingenieros describe una ceremonia a la que asistió llevado por una mujer negra, de la siguiente manera: "Solían reunirse a 'bailar el santo'... Al son de tamboriles y otros instrumentos africanos se hacían ofrendas en especies ante un altar afro-católico, en que se mezclaban estampas, santos, útiles de cocina, sartas de cuentas de vidrio, caracoles, comestibles, bebidas, armas, patas de gallo, cuernos de animales, plumas, etc. El sacerdote o brujo hacía invocaciones en su lengua africana que, a veces, eran repetidas o coreadas por la concurrencia, hasta que alguna de las negras presentes se ponía a bailar, agitándose cada vez más, hasta caer presa de un ataque histero-epileptiforme, seguido de un sopor cataleptoideo, que, según la protagonista duraba pocos minutos o varias horas. Ya el 'santo' (nombre colectivo del altar o de alguna imagen), estaba 'bailado'; entonces el brujo operaba con palabras y con las manos sobre el enfermo, si estaba allí, o le enviaba algún talismán o amuleto, por medio de sus parientes, si su enfermedad impedía traerlo" (en Frigerio 2001, pp. 2, 3).
} 
Una antigua esclava que conocí siendo yo muy joven y ella ya muy vieja, Donata se llamaba, de grandes ojos y muy tiesa todavía, a pesar de sus años, lo que le daba un aire de dignidad a imponer, apenas oía remedar el tamboril, de cualquier modo, se desasosegaba y decía: -¡No hagan eso muchachos!

Si seguíamos un instante más nuestro tamborileo, la pobre negra $[\ldots]$ entornaba sus ojos y comenzaba a bailar hipnotizada; y así que volvía en sí, comenzaba a reír, mostrando su dentadura que brillaba aún como un collar de perlas, y parecía decirnos: -Yo no tengo la culpa. ¿Para qué me hablan de aquella vida soberbia, deliciosa? (Pedro Figari, 1927, en Sanguinetti 2002, p. 28).

Por otro lado, este exotismo se retroalimentó en el ámbito del arte a partir del contacto que tomaron artistas europeos con las producciones africanas, producto del saqueo colonial sobre sus territorios. Schwartz (2006) comenta la manera en que el negrismo, como manifestación de una vanguardia latinoamericana en los años '20, está vinculado a las relaciones anteriores que la vanguardia parisiense de las primeras décadas del siglo XX había tenido con el arte africano. "La búsqueda del exotismo, la introducción de una estética basada en la plástica de los fetiches africanos o de las máscaras polinesias y el regreso a los elementos primitivos de la cultura" son los factores determinantes de estas nuevas reglas de composición (2006: 659). Y muy interesante es el vínculo que estas producciones tuvieron con los primeros estudios antropológicos realizados sobre estas supuestas "culturas 
primitivas". Los cuales, desde una perspectiva anclada en el evolucionismo, consideraban a estas culturas como atrasadas, previas, inferiores, lo cual servía de fundamento en la búsqueda por crear un arte pre-moderno, fuera de los preceptos de una burguesía capitalista en alza.

Es decir, este discurso plástico producido por una elite artística blanca y europea, para ser consumido por un público perteneciente al mismo grupo social, fue construido sobre la base de pensamientos fuertemente racistas, cuando no higienistas y eugenésicos. Esto no quiere decir que los artistas sostuvieran abiertamente estas ideas, pero sí que no las criticaron y que, de algún modo, aprovecharon esta alterización como un modo de subvertir su propia mismidad. Lo que sí es cierto es que este negrismo no se convirtió invariablemente en "negritud"; es decir, en un movimiento de reivindicación de los derechos negros. Dice Schwartz: "las manifestaciones artísticas europeas inspiradas en el negrismo, aunque hayan revolucionado el arte moderno, no son una tendencia ideológica de fondo liberacionista" (2006, p. 660). En este sentido, la vanguardia latinoamericana que produce su propia versión negrista, con elementos del propio contexto afroamericano, tiene diferentes vínculos con los procesos de negritud que se dan en las décadas siguientes, y no puede descartarse que haya habido cierta relación entre este interés por lo negro con la toma de conciencia sobre la realidad vivida por los afrodescendientes en el continente. De todas maneras, fueron procesos paralelos y producidos según sus propias lógicas. 
Volviendo a Figari, es probable que su producción haya estado influenciada por estas ideas primitivistas y negristas que circulaban en los ámbitos artísticos más renombrados. En agosto de 1925, Figari partió rumbo a París, donde permanecería hasta 1934. Allí participó con algunas de sus obras en la exposición L 'Art negre presentada en el Musée des Arts Decoratifs. No por casualidad lo llamaron el "Gauguin uruguayo" (Pandre 2014, p. 6), siendo que, según Schwartz, Paul Gauguin fue probablemente el mejor representante de una camada de artistas que, en respuesta a la crisis de los valores europeos, redujeron los elementos africanos a "ambientes y sonidos, a la descripción del negro por lo que tiene de exótico, a la mitología de su sensualidad y a la nostalgia de un universo primitivo" (2006, p. 661). Procesos que los estudios poscoloniales han sabido retratar muy bien en diferentes aspectos, vinculados a la construcción de Europa bajo el lente de la exotización de los no-europeos.

En algún sentido, creo que algo de este proceso ocurre en Figari, pues para retratar lo propio nacional, lo contemporáneo y lo futuro de un Estado en construcción, es preciso elaborar un pasado remoto, considerado "perdido", lleno de fascinación y exotismo, pues es esa barrera lo que lo aleja del presente. En parte, es la misma operación de extrañamiento. Sobre todo si tenemos en cuenta que, en su contemporaneidad, la realidad de los negros estaba viva, no muerta, y probablemente haya 


\section{estado urgida de una atención mucho más politizada y crítica hacia su realidad ${ }^{4}$. Unas últimas citas de Figari para ilustrar:}

Lógico es que los negros incorporados a la vida colonial tomaran las actitudes de los amos, y las acoplaran a sus modalidades propias. De ahí un abigarramiento lleno de incoherencias y contrastes, el cual se presta admirablemente al humorismo. Ya, las indumentarias ciudadanas, daban aspecto cómico a los negros, y esto agregado a lo otro ofrecía un sabroso pintoresco que no sé cómo pudo escapar inadvertido a los artistas. Donde podía verse mejor todo esto es en la fiesta de ellos, el 6 de enero, día de reyes, para la cual se iban preparando durante el año, no sin que cada tribu designase a sus reyes (pareja de rey y reina) los que comenzaban el día por visitar al gobernador y al

\footnotetext{
4 Sobre este tema, recomiendo retomar los trabajos de Lea Geler (2010) sobre los periódicos afroargentinos en el período de 1876 a 1882; en ellos, la autora señala la existencia de un profundo interés de esta comunidad por la realidad de la nación. Al ser ciudadanos argentinos, muy tempranamente en relación con otros países de Latinoamérica -pues los afrodescendientes votaban, y sus votos eran requeridos- ellos conocían, discutían y estaban muy cerca del mundillo político y de los proyectos que la elite ilustrada iba proponiendo. Geler comenta una discusión muy ilustrativa que se da entre los intelectuales afroporteños sobre si fundar o no un colegio para niños de color a causa de la discriminación que sufrían. Al ser una población pauperizada iban al colegio cansados, no recibían la misma educación y por lo tanto no egresaban en la misma proporción. Sin embargo, cuando la comunidad se organizaba frente a estos casos de discriminación el Estado los apoyaba, pues fomentaba la integración, en pos de una nación homogénea. Entonces, comenta la autora, ellos decían: “¿Por qué vamos a invertir nuestro dinero en fundar escuelas para chicos de color si a la larga el Estado igual nos da lugar en las escuelas públicas? Y nosotros como ciudadanos argentinos no sólo ponemos dinero para las escuelas públicas, sino que vamos a las armas. Todos estos derechos que tenemos, los ganamos nosotros también. ¿Por qué nos vamos a separar de este proyecto de nación?” (Entrevista a Lea Geler en el diario Página 12, del 31 d julio de 2017, en: https://www.pagina12.com.ar/53525-la-desaparicion-afro-en-la-argentinaes-un-mito). Este debate da cuenta de la complejidad que supuso ese proceso de integración para los mismos afrodescendientes, y demuestra cuan viva estaba su presencia en ese contexto.
} 
Cuerpo Diplomático, lo más emperejilados que les era dado presentarse. Se les daban unos pesos para las fiestas por los visitados, y contentos, ufanos, iba cada pareja a presidir su candombe. Duraba la fiesta todo el día y la noche. No era raro que algún negro a fuerza de zangolotearse cayera desplomado, rendido por la fatiga, que en un día canicular como era éste, se hacía sentir doblemente (En Pandre 2014, pp. 22-23).

Yo no sé lo que piensan y sienten ante sus obras los artistas, pero puedo decirle que yo, después que he pintado, al mirar los personajes insinuados, quedo riendo, contento y hasta sorprendido a veces, de la humanidad que trasuntan, así esbozados; y los negros más, pues son de un humanismo genuino, pura uva, como dicen por allá (carta a Eduardo Salterain y Herrera, en 1933, en Pandre 2014, p. 18).

Así, su técnica plástica también da cuenta de esta necesidad por retratar un pasado cargado de sensaciones, emociones y percepciones "vivas", tal vez "urgentes". Es sugerente que haya apelado con sus trazos a la sensualidad de los negros, pues el racismo, en parte, se sostiene a través de vínculos que están profundamente encarnados y que se reproducen a partir de discursos que son orales, pero sobre todo, sensuales. 


\section{Trazos vanguardistas}

Mi pintura consiste no en describir sino en sugerir lo que nos es dado descubrir de poético en las observaciones, recuerdos, evocaciones e impresiones y demás estados psíquicos. De tal suerte no es el modelo objetivo ni objetivado lo que me interesa sino la reacción psíquica experimentada. Pinto derechamente lo de adentro, pues, no lo de afuera (Figari en Fontán, 2012).

Llegado este punto de la argumentación, considero importante volver sobre la idea de las imágenes performativas. Mi pregunta hacia la obra de Pedro Figari ronda, entonces, en torno a la "reacción psíquica experimentada", que es, como vemos en la cita, el objetivo explícito del pintor, en un contexto clave de invisibilización de los afrodescendientes, en toda la zona del Río de la Plata. ¿Cómo y por qué producir una reacción de estas caracterísitcas? Como dice Lyneise Williams (2010), cuando comenzó a pintar a los negros en 1919, Figari tomó la decisión de ir en contra del estilo representacional presentado por los pioneros uruguayos como Rafael Barradas (1890-1929) y Pedro Blanes Viale (1878-1926). Aunque ellos no se dedicaron a esta temática, en los pocos cuadros en que lo hicieron, mantuvieron las formas proporcionales y los colores realistas. Figari eligió una trayectoria diferente, eligió un estilo naif con claros trazos del modernismo parisino. 


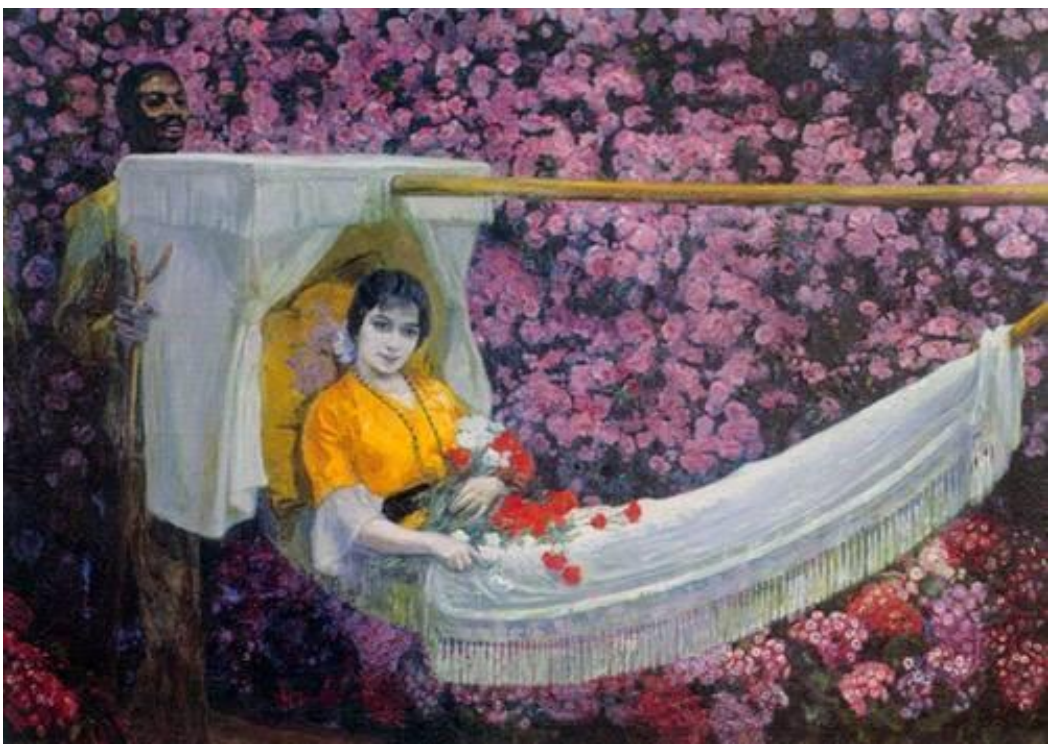

Fig 3. Pedro Blanes Viale, Recuerdo de la Isla madera, 1915

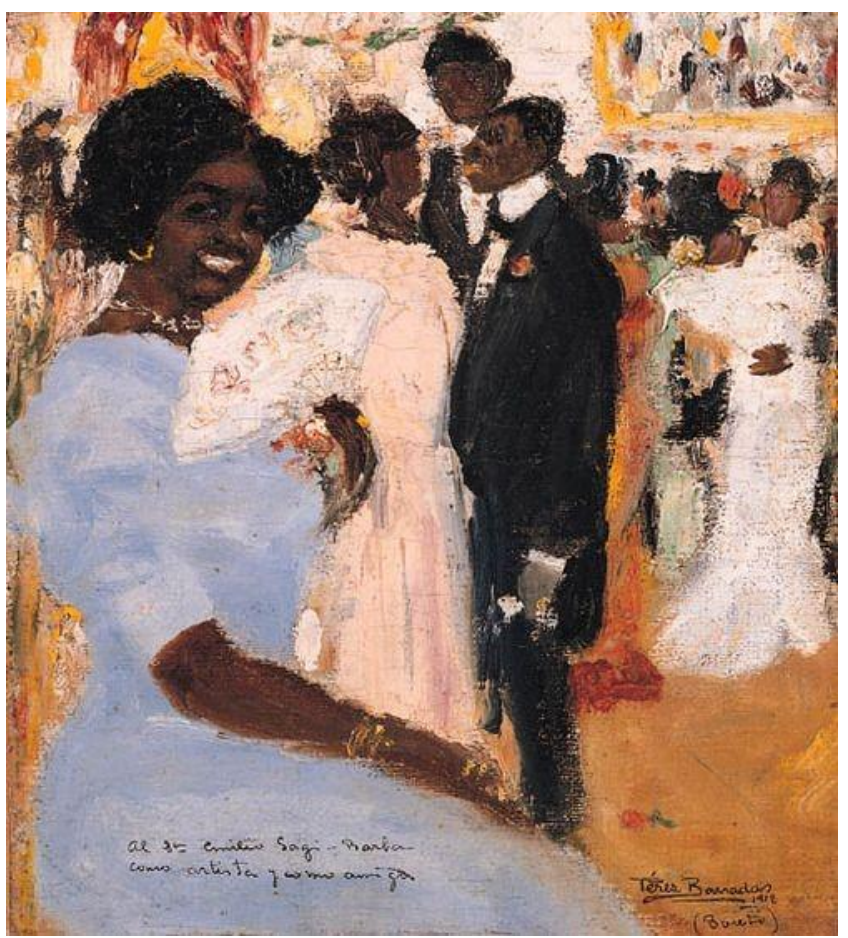

Fig 4. Rafael Barradas, Baile de Negros, 1912 


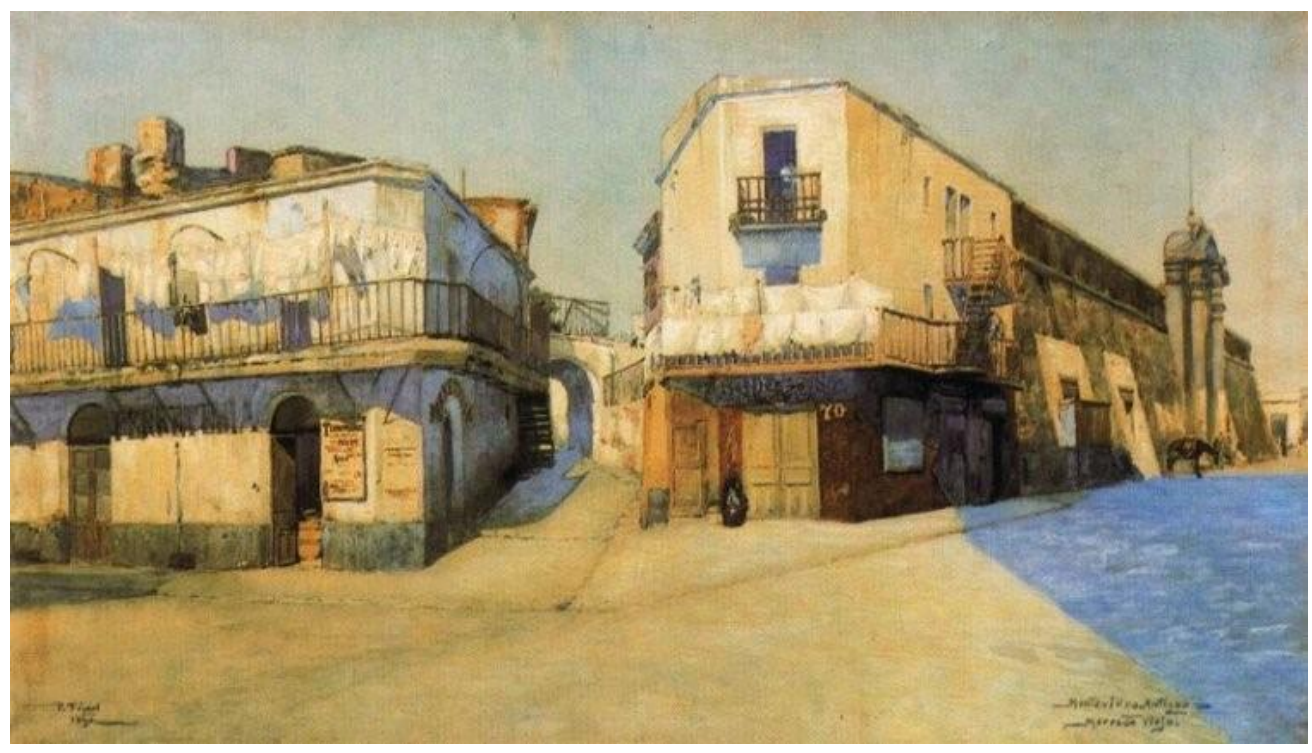

Fig 5. Pedro Figari, El viejo Mercado, 1907

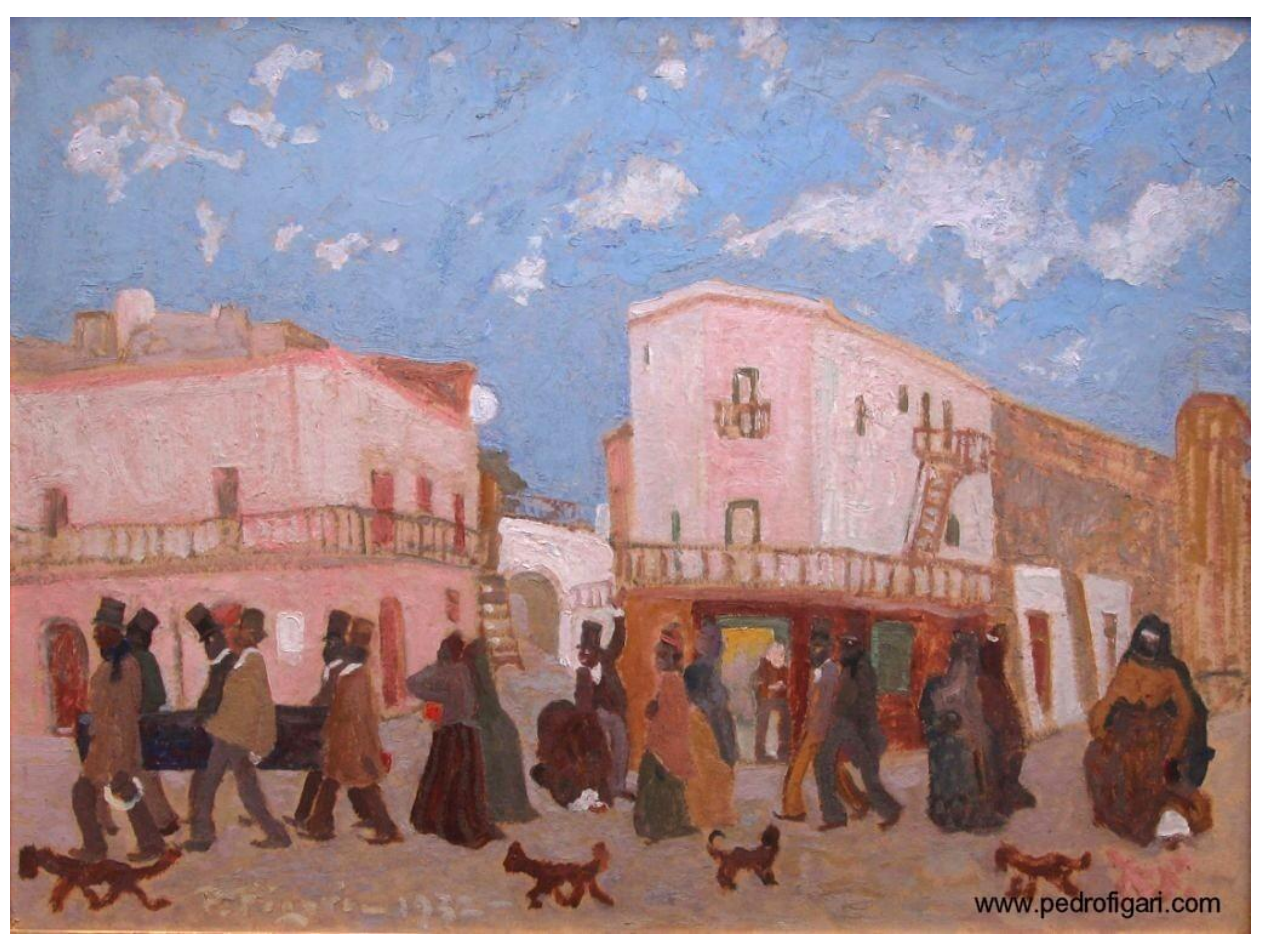

Fig 6. Pedro Figari, Entierro frente al mercado, 1932 
En este cambio de estilo de su obra pictórica, que se puede ver con claridad cuando se compara "El viejo Mercado" de 1907, con "Entierro frente al Mercado", de 1932, Figari aplana las formas, recurre a pinceladas más libres y sustituye la precisión de las líneas por paneles de colores suaves. Esta transformación de estilo para representar una nueva temática, en un principio, no fue vista con buenos ojos por las audiencias uruguayas $y$ argentinas. Ellas expresaron abiertamente su oposición a las pinturas de estilo faux-naïf de Figari en sus primeras exposiciones en 1921, con frases del tipo: "un insulto para la sociedad montevideana" por "presentar públicamente esos hombres y mujeres negros y esos perros hambrientos" (Williams, 2010, p. 185, traducción propia) $)^{5}$.

\footnotetext{
${ }^{5}$ Otra cita que puede resultar ilustrativa del pensamiento racista de la época, y de la opinión sobre el trabajo de Figari, lo encontramos en una nota de Mario Falcao Espalter para La Prensa (sección segunda, Buenos Aires, 1-1-1927), bajo el título "El escultor Zorrilla de San Martín", sobre el monumento montevideano al gaucho: " [...] Será un monumento espléndido. [...] La vulgaridad del arquetipo del criollismo tradicional había tornado casi imposible su reconquista por el arte plástico, porque el gaucho no ha sido un ser pulcro, capaz de redimirse tan fácilmente de sus impurezas al ser fundido en la fragua que consagrara su efigie. Sin ir más lejos, estaba el problema de etnología artística: ¿sería indio, pardo, mulato, blanco? (...) José Luis Zorrilla ha embellecido al gaucho, no cabe duda. Para hacerlo entrar en el arte había que posar en su rostro la grandeza moral de la epopeya de la Independencia. Esta cruzada refluye sobre el artesano que la realizó, y de ahí el tipo caucásico indispensable para exaltarlo a la categoría estatuaria. Es un tipo representativo, el gaucho, creado en el monumento que elogio. Los países del Sur somos de raza caucásica. El mestizo, como dijo lord Bryce en su libro "Les républiques Sud Américaines" (Londres, 1912), no forma ni siquiera una clase aparte entre nosotros. Quédese para las extravagancias del doctor Pedro Figari el imaginar una 'sociabilidad' africana con saraos y galeras de felpa motuda, digna de una ópera, pero no de la historia, ni siquiera de la crónica rioplatense... Zorrilla de San Martín ha exaltado al gaucho con arte y con verdad, la verdad esencial que cabe en los términos augustos de la belleza [...]". Recuperado de http://alejandrofrigerio.blogspot.com/2013/06/la-bellezacaucasica-del-gaucho-1927.html.
} 
Sin embargo, su obra sí se hizo sentir en otros circuitos artísticos e intelectuales: el de aquellos jóvenes que aspiraban a conformar la nueva vanguardia americana. Según Artundo, Figari fue un referente intelectual para la generación de artistas uruguayos y argentinos que se vincularon con la Europa de posguerra experimentando de manera directa los proyectos vanguardistas, y participando de diverso modo en ellos. En este sentido, dice la autora, Europa seguía actuando como un espacio de aprendizaje en tanto era por un lado repositorio cultural del mundo occidental y, a la vez, puente de comunicación con culturas de otros tiempos y espacios. Sin embargo, el quiebre producido por la Primera Guerra Mundial daba a los calificativos de "Viejo Continente" o "Viejo Mundo" una carga semántica negativa: Europa era también lo "viejo" y lo "gastado". En ese contexto, América se prefiguraba como una esperanza nueva y era necesario encontrar lo propio, lo distintivo (Artundo 2000a, p. 2).

A esto se sumaba una tensión entre glorificar lo autóctono, pero a la vez modernizar los medios de expresión, preocupación que ya estaba presente en Figari de alguna manera. La exigencia de crear un lenguaje nuevo para retratar cuestiones tradicionales superando el concepto de fidelidad o copia del mundo exterior, eran también sus premisas. Podría pensarse que existe cierta contradicción entre la creación genuina de un arte autóctono, de voluntad americana, compartida y nueva, y la incorporación de iconografías y estéticas prehispánicas y negristas a la manera del primitivismo francés. Esto fue señalado por Artundo (2000a, p.4) cuando se diferencia de la perspectiva adoptada por otros críticos 
respecto de esta "antropofagia" vanguardista. Desde mi punto de vista, podría no plantearse como una contradicción esta voluntad americanista con la persistencia de un primitivismo negrista, pues es parte de un proceso que se da también en otros ámbitos por el cual se subsume la diferencia racial y étnica en pos de una igualdad de clases, por ejemplo. Incluso en una perspectiva militante, revolucionaria, que insiste en una autonomía e independencia económica y cultural de Europa, existió una ceguera respecto a las diferencias raciales como marcaciones distintivas en el concierto histórico de los pueblos latinoamericanos (Segato 2007). Con esto quiero decir que una voluntad emancipatoria no necesariamente está atenta a estas diferencias, por ejemplo de raza o de sexo/género. Y que incluso la diferencia cultural (por ejemplo al interior de una nación) puede ser pensada como un obstáculo a la hora de conducir una "revolución proletaria", pues en nombre de la clase todas las otras variables quedan anuladas. Y en este caso estoy pensando en las vanguardias posteriores, más vinculadas a los procesos revolucionarios de América Latina, las cuales tampoco se detuvieron en problemáticas que intersectaban la disparidad de los lugares ocupados en el sistema de producción capitalista (como puede ser el racismo o el heterosexismo). De todos modos, en este contexto que estamos analizando, el de las primeras décadas del siglo XX hasta el fin de la primera guerra mundial, la búsqueda de una identidad americana por parte de un sector social acomodado, desde la fascinación hacia aquellos sectores más relegados, pensando en ellos como cosa antigua, primitiva, del pasado, deja entrever una profunda incapacidad para actuar más allá del colonialismo, impuesto no 
sólo en términos económicos, sino fundamentalmente epistémicos, al decir de Quijano (1993). Habrá que analizar cómo, en cada caso, esa fascinación primera se vuelve o no puente para una crítica radical, una toma de consciencia de los lugares de cada cual en esa historia de opresión.

Por otro lado, es probable que, en el caso de Figari que responde más a las inquietudes de la generación del ' 80 que a la del '20, su voluntad nacionalista, moderna, afín a la industrialización, la educación y la homogeneización cultural, le impida ver en la realidad diferencial de los afrodescendientes alguna positividad. Como para muchos otros intelectuales de la época, la diferencia racial y étnica eran más un problema a resolver que una promesa de diversidad y riqueza.

En este sentido, como dijimos, hay que pensar en el intenso proceso de modernización e inmigración masiva que vivían estos países, lo que había obligado a sus intelectuales a encontrar qué era lo que estaba en los orígenes de nuestra identidad, de lo "nacional", cuál era la lengua propia o cuál debía ser el fundamento de la educación. En este contexto, Figari había decidido hacer una recuperación visual de un pasado "ya desaparecido" y en la que revivían las tradiciones rioplatenses. Esta problemática, nos dice Artundo (2000a), lejos de haberse diluido en el tiempo, a comienzos de la década del veinte constituía uno de los principales ejes en torno al cual giraban las discusiones. Por ejemplo, sobre la existencia o no de una mentalidad y sensibilidad argentinas, el uruguayo sintetizó su postura en la revista vanguardista Martín Fierro, diciendo que "reconocía la dificultad para determinar sus características, debido a condiciones específicas que 
dificultaban su aprehensión: la existencia de un territorio de grandes extensiones y con una distribución irregular de su población, cuya composición étnica era además variada" (Artundo 2000b, p. 4). Lo interesante es que, en su relato, esta identidad estaba compuesta por sólo dos vertientes: la autóctona y la europea, no así la negra.

Dice sobre la Provincia de Buenos Aires: "sobre la base colonial, constitutiva del núcleo postcolombiano destinado a perdurar, apareció el hijo del colono: el "criollo", con su espíritu propio. Influído [sic] por dos civilizaciones: la autóctona y la europea, y formado en un medio soberanamente rico" (Figari en Artundo 2000b, p. 4). ¿Qué parte, entonces, ocupaban los negros en la constitución de esa mentalidad y sensibilidad argentina, según Figari? Hoy podríamos decir que, en el devenir histórico de los dos países, claramente en Argentina la africanidad fue ocultada, negada y olvidada (Cirio, 2003; Frigerio, 2008; Geler, 2010; Martin, 2006; Solomianski, 2003), en proporciones muy distintas a como lo fue en Uruguay (Frigerio, 1993; Reid Andrews, 1990); pero en el momento en que el pintor dice estas palabras, probablemente la raíz negra estuviera tan presente en una orilla como en la otra, con sus matices, pero desenvolviéndose paralelamente en ese proceso de reacomodo nacional. Creo que el olvido de Figari de ese componente negro en la identidad argentina, o rioplatense, se debe más a una desvalorización del aporte afro a las nacientes comunidades imaginadas, que a una real inexistencia. En ese marco, ¿qué implicaba pintar a los negros como cosa del pasado?, cuando lo cierto es que sus prácticas seguían vivas, presentes; perseguidas y estigmatizadas, pero 
vigentes. Tal vez su pintura cumplía el rol de reforzar la decisión política de considerar a esos connacionales como perdiéndose en el tiempo, como cosa del pasado. Un poco a la manera de pintar, de trazar "impresionistamente" un discurso plenamente vigente, el del crisol de razas: esa mezcla alquímica en la cual lo heterogéneo se homogeneiza ${ }^{6}$. Así lo dice Artundo, aunque con un énfasis contrario:

Esta era en realidad su definición de raza; en ella superaba las posturas xenófobas respecto de los inmigrantes que habían circulado desde fines del siglo anterior, para afirmar que la capacidad de absorción que poseían estas tierras y sus habitantes -el criollo, es decir, el gaucho urbano o ruralcon su hospitalidad y valentía conducirían en el futuro a una "fusión" de las razas: "Podrá definirse al criollismo como un tributo de incorporación que exige el ambiente de América para ampararse a la ley natural de adaptación, tributo de tal modo espontáneo en su consecución, que lo

\footnotetext{
${ }^{6}$ Algunas citas que ejemplifican el racismo presente en la idea de crisol de razas, que circulaban por la época: "La primera generación es, a menudo, deforme y poco bella hasta cierta edad; parece el producto de un molde grosero, los primeros vaciamientos de la fundición de un metal noble, pero todavía lleno de engrosamientos y aristas que el pulimiento posterior va a corregir. Hay un tanto por ciento de narices chatas, orejas grandes y labios gruesos: su morfología no ha sido modificada aún por el cincel de la cultura. En la segunda, ya se ven las correcciones que empieza a imprimir la vida civilizada y más culta" (Ramos Mejía, 1899, en: Segato nota 14). Y, con mayor énfasis eugenésico: "Cuanto se haga en pro de las razas inferiores es anticientífico; a lo sumo se les podría proteger para que se extingan agradablemente (...) Es necesario ser piadoso con estas piltrafas de carne humana; conviene tratarlos bien (...) Pero sería absurdo tender a su conservación indefinida, así como favorecer la cruza de negros y blancos. La propia experiencia de los argentinos está revelando cuan nefasta ha sido la influencia del mulataje en la argamasa de nuestra población, actuando como levadura de nuestras más funestas fermentaciones de multitudes, según nos lo enseñan desde Sarmiento, Mitre y Lopez, hasta Ramos Mejía, Bunge y Ayarragaray (Ingenieros 1906, en Figari 2012, pp. $22,23)$.
} 
vemos pagar sonriendo a las razas más exóticas, apenas tocan estas tierras". (Artundo 2000b, pp. 4, 5)

Allí se encuentra entonces su eficacia: mediante una técnica precisa sus cuadros congelan una cultura étnica en el pasado, pintan un cuerpo negro exótico, pintoresco, ajeno a la realidad contemporánea que ha fusionado a las razas y que no puede ver ya más a los afrodescendientes como actores que sobreviven al contexto poscolonial hostil. De alguna manera, como dice Williams (2010), aprovecha el "circuito colonial": se hace apreciar en Paris, afina su estilo primitivista, para volver valioso a su lugar de origen a contar que hubo negros, en el pasado, como parte de la tradición. Fue necesario introducir este primitivismo en la percepción de la propia diferencia racial americana, para que ese legado negro cobrara visibilidad y aprecio en los circuitos intelectuales y artísticos de la nación blanca.

\section{Palabras finales: archivos vs. repertorios, o de cómo Pedro Figari no representó a los afrouruguayos contemporáneos}

Las producciones artísticas no son inocentes. Los contextos de producción hacen a la eficacia de los mensajes que las obras quieren transmitir, y entran en el juego social disputando lugares de enunciación, producción de referencialidad, creación de mundo. Mi interés por la obra de Pedro Figari no fue estrictamente estético; aunque sí, en algún punto. En todo caso, me preocupó su estética en los términos de la eficacia 
performativa que tuvieron las imágenes que él construyó sobre los negros, buscando comprender la manera en que incidieron en la elaboración de un imaginario racial profundamente sensual, sensitivo. Qué cuerpos negros representó, y cómo se articula este imaginario con un cuerpo legítimo no-negro. Pedro Figari, abogado, hijo de inmigrantes italianos comerciantes con aspiraciones de escalar en la pirámide social, disputaba también, como dice Williams (2010), su misma blanquitud al interior de la elite criolla de la época. En cierta manera, plantea esta autora, su creación de los negros uruguayos fue una estrategia también para darse un lugar, para legitimarse, no sólo como abogado y político, sino como artista criollo en un Uruguay en formación. En un contexto sociopolítico signado por la heterogeneidad cultural y racial, y de profunda segregación social anclada en la diferencia, los cuerpos negros jugaron, y juegan aún hoy, un lugar especial en esa disputa por pertenecer al cuerpo de la nación, por hacerse de un propio cuerpo legítimo. Este juego es necesario comprenderlo para analizar las relaciones raciales poscoloniales en nuestros contextos, y el lugar que le cupo a cada quién en estas negociaciones de fuerte carácter biopolítico.

En el proceso de elaboración de las normativas que regularon los cuerpos legítimos e ilegítimos de la Nación, el discurso del arte se ensambló con aquellos letrados que, desde sus lugares de enunciación como saberes expertos, instituyeron verdades y memorias. En este contexto que estamos analizando, el de las primeras décadas del siglo XX hasta el fin de la primera guerra mundial, la búsqueda de una identidad americana por parte de un sector social acomodado, se 
produce desde la fascinación y el rechazo hacia aquellos sectores relegados y racializados (indios, negros y mestizos), pensando en ellos como cosa antigua, primitiva, del pasado, lo que deja entrever una profunda incapacidad para actuar más allá del colonialismo, impuesto no sólo en términos económicos, sino fundamentalmente epistémicos y ontológicos. En el caso de Figari, entiendo que hay un efecto de normalización de los cuerpos que sus cuadros producen, delineando el tipo de cuerpo y el tipo de cultura que los negros pueden tener en esta zona. De allí la necesidad de pensarlo como parte del engranaje institucional, a la manera de un dispositivo de la maquinaria biopolítica, que alimentó el imaginario racial local.

Figari continúa ocupando el lugar del "pintor que representó la cultura afrouruguaya", hasta la actualidad. Ante esta aseveración, me pregunto: ¿qué cuerpo negro es posible de ser representado en el Río de la plata, ayer y hoy? ¿Cuánto ha cambiado esa representación que asocia: negros-candombe colonial-bailes-desenfreno-barbarie? ¿Hay forma de representar, de performativizar y así legitimar, otro tipo de cuerpo negro? ¿O de cuerpo no-blanco? ¿Cómo es posible que ese legado de Figari no haya sido retomado por ningún otro pintor de la zona, ese interés por lo negro? En parte, esta ausencia podría ser producto de lo que Geler (2016) denominó, para Argentina, como el pasaje de la negritud racial, a la negritud popular. Los negros de Berni, por ejemplo, son los negros populares, los así llamados "cabecitas negras". Ya no hay referencia a la raza. Se ha perdido la capacidad de representar la diferencia racial, incluso en forma estereotipada, 
pues lo racial ha dejado de pertenecer a estas tierras. Sin embargo, en Uruguay, esa presencia es abrumadora, aunque también negada. Y tampoco es fácil encontrar quién cuestione la asociación negro-candombe, menos aún luego de la patrimonialización del Candombe. ¿Cómo se produce esa asociación? En parte es el resultado de este proceso de racialización que he intentado señalar aquí, que opera fijando archivos, mientras disciplina y niega repertorios (Taylor 2003) ${ }^{7}$. Es el resultado de una tensión entre el archivo como la fijación de un imaginario sobre los negros vs. un repertorio estigmatizado, que fue obligado a desaparecer, a esconder, a pulir, a normalizar y a civilizar porque performativamente expresaba rasgos "anti-nacionales": incivilizados, sexualizados, esotéricos, articulando raza, sexo, religión y nación ${ }^{8}$.

¿Cómo afecta este archivo hoy? En el engranaje de la racialización, producto de esta biopolítica sobre los cuerpos, sigue funcionando como "lo verdadero" de los negros, como fuente de lo que era su cultura, como un código que se pone en acto en nuevas performances, afectando nuevos repertorios. Un archivo que se reorganiza en las performances actuales, por ejemplo, cuando es preciso visibilizar una identidad o una cultura afroargentina, a la manera de un capital simbólico, y me

\footnotetext{
${ }^{7}$ Retomo aquí la distinción de Taylor sobre los diversos modos de "producir, almacenar y transmitir conocimiento" (en tanto "información, memoria, identidad y emoción"): de manera directa, mediante "repertorios" de performances que se transmiten de generación en generación y que "ponen en escena la memoria incorporada"; y mediante "archivos" materiales -que existen en "documentos, mapas, textos literarios, cartas, restos arqueológicos, huesos, videos, películas, discos compactos"- que resisten el paso del tiempo y producen una distancia entre el momento de producción y el de recepción (2003:19-20).

8 Trabajé esta articulación para el caso de la estigmatización de las religiones afrobrasileñas en la ciudad de Rosario en: Rodriguez (2017)
} 
arriesgaría a decir, un capital performativo que, puesto en acto, produce cuerpos e identidades actuales. Lo que intento decir es que pareciera que es preciso reproducir, citar este archivo para "ser negro" en estas tierras, para legitimarse ante la mirada ajena; algo que encuentro frecuentemente en las etnografías sobre prácticas "afros" (de afrodescendientes y de noafrodescendientes). Sin dejar de reconocer la reflexividad corporizada (Rodriguez 2009) que puede producir poner en acto este capital performativo (en la elaboración de nuevos vínculos, ocupando espacios vedados, reconociéndose en la diferencia) me pregunto también por la posibilidad de subvertirlo, construyendo otros registros que fisuren los imaginarios raciales vigentes, aumentando ese capital, cuestionándolo, dándole otros matices, otras formas y otros contenidos que puedan ser legítimos en nuestros contextos regionales y que puedan ser utilizados para proyectar otros cuerpos e identidades no-blancas.

\section{Referencias bibliográficas}

Artundo, P. (2000a). "Los años veinte en la Argentina. El ejercicio de la mirada". En: CiberLetras, $\mathrm{n}^{\mathrm{o}} 3$, agosto. Recuperado http://www.lehman.cuny.edu/ciberletras/vo3.html.

(200ob). "Pedro Figari y la nueva generación argentina: La problemática latinoamericana". En: Cuartas Jornadas "Estudios e Investigaciones: Imágenes, Palabras, sonidos. Prácticas y Reflexiones". Instituto de Teoría e Historia del Arte "Julio E. Payró". F.F. y L. UBA. 
Babha, H. (2002). "La otra pregunta. El estereotipo, la discriminación y el discurso del colonialismo". En: El lugar de la cultura. Buenos Aires: Ed. Manantial.

Butler, J. (2004). "Introducción”. Lenguaje, poder e identidad. Madrid: Síntesis, pp. 15-78.

(2007). El género en disputa. Buenos Aires: Paidós.

(2008). Cuerpos que importan. Sobre los límites materiales y discursivos del "sexo". Buenos Aires: Paidós.

Castro Gomez, S. (2014). "Cuerpos racializados. Para una genealogía de la colonialidad del poder en Colombia". Hilderman, Cardona and Zandra Pedraza (Comp.) Al otro lado del cuerpo. Colombia: Universidad de Medellín Universidad de los Andes.

Catelli, L. (2017). "Lo racial como dispositivo y formación imaginaria relacional” Revista Intersticios de la política y la cultura, vol. 6, núm. 12, 89-117

Cirio, P. (2003). "La desaparición del candombe argentino. Los muertos que vos matáis gozan de buena salud". Música $e$ Investigación, 12-13, 181-202.

Citro, S. (1997). "Cuerpos festivo-rituales: un abordaje desde el rock". Tesis de Licenciatura, Universidad de Buenos Aires.

(2001). "El cuerpo emotivo: de las performances rituales al teatro". Elina Matoso (comp). Imagen y representación del cuerpo. Buenos Aires: Universidad de Buenos Aires, Facultad de Filosofía y Letras, 19-34.

(2006). "El análisis de las performances: las transformaciones de los cantos-danzas de los toba orientales". Pablo Schamber y Guillermo Wild (comp). Simbolismo, ritual y performance. Buenos Aires: S/B, 83-119.

De Oto, A. y Bulo V. (2015). "Piel inmunda: La construcción racial de los cuerpos", Mutatis mutandis: Revista Internacional de Filosofía, 5, 7-14. 
Fanon, F. (1973). Piel negra, máscaras blancas. (Trad. A. Abad). Buenos Aires: Abraxas

Fontán, A. (2012). "Anagnórisis en las danzas de Figari”. Suite para Figari. Pintura, música, danza: narrativas de la identidad, Museo Figari, Dirección Nacional de Cultura, Ministerio de Educación y Cultura, Montevideo, Uruguay.

Foucault, M. (1977). Historia de la sexualidad. 1-La voluntad de saber. Madrid: Siglo XXI.

(2000). Defender la sociedad. Buenos Aires: FCE. Aires: FCE.

(2006). Seguridad, territorio y población. Buenos

Frigerio, A. (1993a). "El Candombe Argentino: Crónica de una muerte anunciada". Revista de Investigaciones Folclóricas 8, 50- 60 .

(2006). "Negros" y "Blancos" en Buenos Aires: Repensando nuestras categorías raciales". Temas de Patrimonio Cultural, 16, 77-98.

(2008). "De la "desaparición" de los negros a la "reaparición" de los afrodescendientes: Comprendiendo la política de las identidades negras, las clasificaciones raciales y de su estudio en la Argentina”. G. Lechini (comp). Los estudios afroamericanos y africanos en América Latina: herencia, presencia y visiones del otro. Buenos Aires: CLACSO.

Geler, L. (2010). Andares negros, caminos blancos. Afroporteños, Estado y Nación Argentina a fines del siglo $X I X$. Lugar: Rosario

(2016). "Categorías raciales en Buenos Aires. Negritud, blanquitud, afrodescendencia y mestizaje en la blanca ciudad capital”. Runa vol. 37, núm.1.

Laluz, A. (2012). "Tramas narrativas: arte e identidad cultural", en: Suite para Figari. Pintura, música, danza: narrativas de 
la identidad, Museo Figari, Dirección Nacional de Cultura, Ministerio de Educación y Cultura, Montevideo, Uruguay.

Martin, A. (2006) "Presencias ausentes: El legado africano a la cultura argentina”. Temas de Patrimonio Cultural 16, 205216.

Merleau-Ponty, M. (1993). Fenomenología de la percepción. Buenos Aires: Planeta

Pandre, A. (2014). Tesina de Licenciatura en Arte: "El candombe en la obra de Pedro Figari", Universidad de Palermo, Facultad de Humanidades y Ciencias Sociales.

Quijano, A. (1993). “'Raza', 'Etnia' y 'Nación' en Mariátegui: Cuestiones Abiertas". Roland Forgues (ed.): José Carlos Mariátegui y Europa: La Otra Cara del Descubrimiento. Lima: Editora Amauta

Reid Andrews, G. (1990). Los Afroargentinos de Buenos Aires. Buenos Aires: Ediciones de La Flor.

(2006). "Recordando África al inventar Uruguay: sociedades de negros en el carnival del Montevideo, 865-1930”. Revista de Estudios Sociales, 26, 86-104.

Rodriguez, M. (2007). "Cuerpos femeninos" en la Danza del candombe montevideano. Tesis de Licenciatura. Archivo de la Facultad de Humanidades y Artes, Universidad Nacional de Rosario.

(2009). "Entre ritual y espectáculo, reflexividad corporizada en el candombe”. Revista Avá 14, 145-161.

(2016). Giros de una Mae de Santo. Corporalidad $y$ performatividad en un caso de conversión a las religiones afrobrasileñas en Argentina. Tesis doctoral. Archivo de la Facultad de Filosofía y Letras. Universidad de Buenos Aires.

(2017). "Re-conocimiento de las religiones afrobrasileñas en Rosario: racconto de un proceso de 
segregación social”. Revista de la Escuela de Antropología XXII, 99-128.

(2018). "La incorporación espiritual como performance: hacia una teoría de la subjetividad performativa”. J. M. Renold (Comp.) Antropología Social. Perspectivas y problemáticas Vol. 3, Rosario: Laborde Editor, pp. 459-496.

Schechner, R. (2000). Performance. Teoría y prácticas interculturales. Buenos Aires: Libros del Rojas, Universidad de Buenos Aires.

Sanguinetti, J. M. (2002). El doctor Figari. Montevideo: Aguilar Ed.

Schwartz, J. (2006) "Negrismo y negritud". Las vanguardias latinoamericanas. México: F.C.E.

Segato, R. (2007) [1991]. "Una vocación de minoría: la expansión de los cultos afro-brasileños en la Argentina como proceso de re-etnización". La nación y sus otros. Buenos Aires: Prometeo Libros, pp. 243-272.

Solomianski, A. (2003). Identidades secretas: la negritud argentina. Rosario: Beatriz Viterbo Editora.

Taylor, Diana. (2003). The Archive and the Repertoire. Performing Cultural Memory in the Americas. Duke University Press: Durham.

Williams, Lyneise E. (2010). "A Different Shade of Modernism. Difference and Distinction in Pedro Figari's Representations of Black Bodies". Mary D. Sheriff (Ed.) Cultural Contact and the Making of European Art since the Age of Exploration. The University of North Carolina Press. 